\title{
Effect of Fungus Meripilus giganteus (Pers.) $P$. Karst. on Occurrence and Development of False Heartwood and Rot in Fagus sylvatica L. Round Wood
}

\author{
Krunoslav Arač, Jelena Kranjec Orlović, Danko Diminić
}

\begin{abstract}
Common beech is one of the most widespread and important European tree species, widely used in timber industry and for energy production. Under specific set of complex factors, it facutatetivly develops false heartwood, which considerably decreases market demand and value of processed logs. Due to its properties, false heartwood is more susceptible to attack of wood decay fungi, which leads to further loss of wood quality and value. One of the most common fungi able to cause heart rot in beech is Meripilus giganteus, known for its spread in the basal parts of the tree, where it can affect most valuable sections of round wood. The aims of this study were to monitor the distribution of fungus and appearance of its fruiting bodies in research area, and to analyze the extent of fungus impact on shape and size of false heartwood and occurrence and length of rot in infected trees, while taking into account the observed stem damage as a possible influential factor. Fruiting bodies occurrence, life span and position on a tree were monitored during a six-year period. For trees with confirmed infection, stem damage was evaluated and appointed to one of four size classes. False heartwood shape and share in associated stem crosssection were observed and measured on 1-4 cross-sections per tree at different heights, and compared between infected and uninfected trees. If present, length of wood decay extent on butt-log was measured. The obtained results confirmed increased susceptibility of mature trees to infection, which seemed to occur mostly via roots from where mycelium spread into stem base. It was found that Meripilus giganteus has a significant impact on enlargement and change of FH shape from cloud- to star-like, up to approximately $5 \mathrm{~m}$ of the stem height, thus causing devaluation of the first assortments. The presence of rot was confirmed on the majority of infected trees, extending averagely $0.5 \mathrm{~m}$ into the first processed log, causing the loss of utilizable volume and thus the value of round wood. Stem damage category showed no significant effect on false heartwood or rot, supporting the prevailing impact of the fungus.
\end{abstract}

Keywords: giant polypore, common beech, false heartwood, heart rot, wood-decay, wood assortments

\section{Introduction}

Common beech (Fagus sylvatica L.) is one of the most widespread forest tree species in Europe, found longitudinally from the Cantabrian Mountains in the west to the Carpathians and Balkan Mountains in the east, and latitudinally from Sicily in the south to Sweden and Norway in the north, on the area of approximately 49 million ha (Magri 2008, Pretzsch et al. 2015). It is extensively distributed in Croatia as well, occupy- ing more than $36 \%$ of the total forest area, from lowlands to mountains (100-1200 m above sea level), and with a share of more than $37 \%$ in the total growing wood stock (Vukelić and Baričević 2003, Čavlović 2010, Anon. 2016). Due to its high adaptability to different soil and climate conditions, common beech is an ecologically and economically very important European species, widely used in timber industry and a renewable energy sector (Zell et al. 2004, Liu et al. 2005, Klement and Vilkovská 2018, Marenče et al. 
2020). In Croatian forestry, common beech is expected to account for more than $35 \%$ of annual cut volume in the period from 2016 to 2025, with a total production of $11,213,479 \mathrm{~m}^{3}$ of processed logs and $13,372,351 \mathrm{~m}^{3}$ of fuelwood (Anon. 2016).

One of the main factors having a considerable effect on the quality and value of processed beech assortments are heart defects, particularly false heartwood (Prka et al. 2009, Račko and Čunderlík 2010, Marenče et al. 2020). In beech, it develops facultatively as an abnormal formation associated with the death of living cells and a discoloration of their contents (Panshin and Zeeuw 1970), and is also referred to as red heart, red heartwood, facultative colored heartwood or red core (Torelli 1984, Sachsse 1991, Wernsdörfer et al. 2005, Bosshard 2013). In comparison to normally developed heartwood in other tree species, it is characterized by uneven brown to red color and different shapes, with borders usually not coinciding with annual growth rings (Sachsse 1991). Although it has not been proven that false heartwood (FH) is of significantly impaired mechanical, technological or adhesive ability properties in comparison with normal beech wood (Seeling and Sachsse 1992, Pöhler et al. 2006), it is much less valued and demanded in the market, achieving more than $50 \%$ lower prices in some cases (Zell et al. 2004). Research conducted in Germany revealed that occurrence of FH can cause the annual income loss of 5.1 million $€$ (Richter 2001). This is mostly due to depreciated aesthetic value, which decreases or completely excludes utilization of red heart beech logs in the veneer and furniture industry (Molnár et al. 2001, Zell et al. 2004, Hapla and Ohnesorge 2005). Substances found in $\mathrm{FH}$, besides diminishing visual properties, significantly reduce the permeability of wood to liquids, affecting the impregnation processes of beech logs (Babiak et al. 1990, Seeling 1998). The presence of $\mathrm{FH}$ also has an effect on the log drying quality, both in terms of more complicated and slower process and final results, primarily color (Marinescu et al. 2010, Barański et al. 2017).

Although the genesis of FH has still not been completely clarified, different authors agree that it is initiated when oxygen enters the stem through wounds or dead tissue, diffuses in the axial direction and gets into contact with parenchyma cells (Zycha 1948, Kucera and Pohler 1988, Seeling 1998, Koch et al. 2000, Knoke 2003, Račko and Čunderlík 2010). This causes oxidation of soluble hydrocarbons and starch in living or partially dead parenchyma cells and production of dark colored polyphenols which are responsible for the change of wood visual appearance (Koch et al. 2001). Simultaneously tyloses are formed from paren- chyma cells, blocking the vessels as a part of tree defense mechanism (Zycha 1948, Necesany 1966, Račko and Čunderlík 2010). Dehydration of the central stem tissue and related decrease in vitality of the parenchyma cells are believed to be a prerequisite for this process (Zycha 1948, Torelli 1984, Bauch and Koch 2001). It is considered that the occurrence and size of $\mathrm{FH}$ increase with tree age, stem diameter and number and size of bark wounds and stem bifurcations, which represent potential oxygen entrance points into the stem (Mahler and Höwecke 1991, Walter and Kucera 1991, Knoke 2003, Sorz and Hietz 2008, Prka et al. 2009, Schmidt et al. 2011, Račko et al. 2018). Growth conditions in the forest stand that have effect on wood quality, such as soil nutrition complex on forest site, can also affect heartwood formation according to some studies (Büren 1997, Furst et al. 2006), although this requires more clarification (Torelli 1984).

Some research indicates that oxygen itself is not a sufficient trigger for the $\mathrm{FH}$ formation and that the activity of microorganisms is involved (Albert et al. 2003, Sorz and Hietz 2008). Despite the fact that tyloses, polyphenols and other substances found in $\mathrm{FH}$ have an inhibiting effect on spread of pathogens (Oven et al. 2010), bacteria and fungi are still able to invade wood tissue and cause intensification and further spread of discoloration (Shigo and Hillis 1973). Abnormal, spattering FH shapes are usually linked to fungal activity (Necesany 1958, Sachsse 1991). Subsequently, wood-decay fungi are also able to colonize $\mathrm{FH}$ and degrade the cell-wall substances, causing the loss of mechanical wood properties, formation of heart rot and further devaluation of beech timber (Wernsdörfer et al. 2005, Trenciansky et al. 2017). Since polyphenols and other defence substances are not equally distributed in the $\mathrm{FH}$, progress of wood-decay fungi in this tissue is uneven and rot is often of heterogeneous, mosaic appearence (Glavaš 1999).

One of the commonly found wood-decay fungi on beech, which is able to surpass defense barriers and cause heart rot, is Meripilus giganteus (Pers.) P. Karst., also known as Giant Polypore. The species is widely distributed across Europe, where it grows on roots and stem bases of live deciduous and coniferous trees and on fallen trees trunks and stumps (Kišpatić 1980, Krisai-Greilhuber 1992, Schwarze and Fink 1998, Zmitrovich et al. 2019). It is characterized as a pathogenic saprotroph, predominatly occurring on beech and oak trees that have reached a certain age and size and suffered of wounding (Zmitrovich et al. 2015, Zmitrovich et al. 2019). The fungus causes white rot (Ryvarden and Gilbertson 1994, Ryvarden and Melo 2017), which means it decomposes the major structural 
polymers in wood cell walls, lignin, cellulose and hemicellulose. Schwarze and Fink (1998) described this process in more detail, discovering that the fungus degrades pectin-rich middle lamellae after delignification of secondary cell wall, leaving a conspicuous hollowing of multiseriate xylem rays in beech wood. The presence of the fungus mycelium inside a beech tree can be recognized on the stem surface only when it forms fruiting bodies, i.e. basidiocarps, which are annual and usually appear in summer and/or autumn (Krisai-Greilhuber 1992, Božac 2003, Friedrich 2006, Schmidt 2006). $M$. giganteus develops large clusters of multiple fanshaped to spatulate fruiting bodies $3-18 \mathrm{~cm}$ wide and long with tapering base, growing from strong common stem (Božac 2003, Tomiczek et al. 2007, Zmitrovich et al. 2019). The fungus requires a significant mycelial mass for the development of its sporulation (Bondartsev 1953), forming basidiocarp clusters up to $1.5 \mathrm{~m}$ in diameter (Nienhaus et al. 1996, Arač 2005, Schmidt 2006, Tomiczek et al. 2007, Jordan 2011).

In the study conducted by Arač (2005) on diversity of wood-decay fungi in common beech stands in Croatia, M. giganteus was found to be the most frequent wood-decay fungus present on living trees and one of the most abundant on stumps, pointing to its significance as a factor affecting quality of beech timber. Therefore, this research was conducted as a follow-up to the previous one, aiming to gain more insight into the role of this fungus in development of beech $\mathrm{FH}$ and heart rot and subsequently into its impact on the devaluation of beech processed logs. The objectives were to:

$\Rightarrow$ estimate the distribution of the fungus and propose guidelines for its recognition by monitoring the appearance and development of fruiting bodies and taking notes on their position on the tree
$\Rightarrow$ determine the effect of $M$. giganteus infection on FH shape by comparing shape categories between infected and uninfected trees

$\Rightarrow$ determine the impact of $M$. giganteus infection on FH size by comparing its share in cross-sections at different stem heights in infected and uninfected trees

$\Rightarrow$ discover the impact of stem damage on shape and size of $\mathrm{FH}$ and presence and spread of associated rot by evaluating the size of mechanical damage on infected trees

$\Rightarrow$ check the extension of $M$. giganteus caused rot into the processed beech logs by measuring its length.

\section{Materials and Methods}

Occurrence of Meripilus giganteus fruiting bodies on trees was monitored in 2005 and in the period from 2010 to 2015 in even-aged common beech forest stands (subcompartments) situated in six forest management units under the jurisdiction of Forest Administration Koprivnica, Croatian Forests Ltd. (Fig. 1). During the six-year monitoring, Meripilus giganteus fruiting bodies were observed on 154 common beech trees in 17 even-aged forest stands in the research area (Table 1). Of those, 74 trees ( 54 cut +20 windthrown) were chosen for further analysis, together with additional 75 trees without signs of Meripilus giganteus infection. All 154 infected trees were marked and their DBH (diameter at breast height) measured. For each infected tree, mechanical stem damage was evaluated and classified according to methodology developed by Čavlović and Božić (2008), with minor modifications, into following categories:

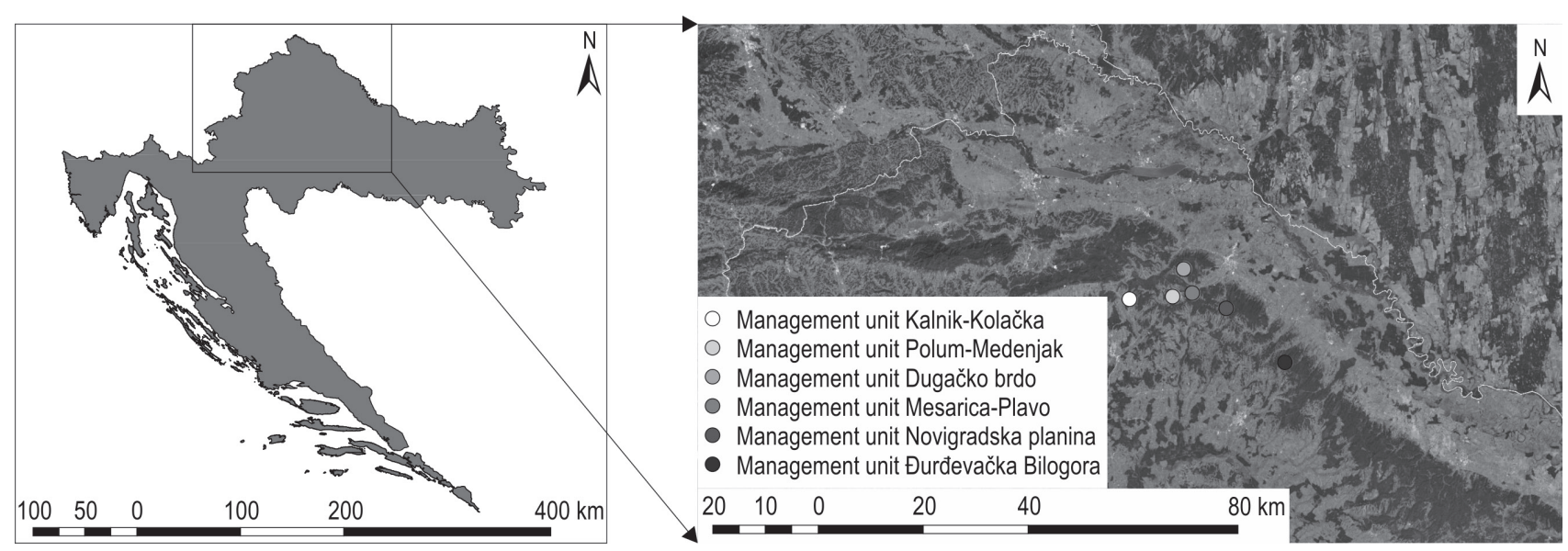

Fig. 1 Area of Forest Administration Koprivnica, Croatian Forests Ltd., where research was conducted 
$\Rightarrow$ Undamaged stem, with no visible mechanical damage

$\Rightarrow$ Slightly damaged stem, with total damaged surface area $\leq 3 \mathrm{dm}^{2}$
$\Rightarrow$ Moderately damaged stem, with total damaged surface area $>3$ and $\leq 10 \mathrm{dm}^{2}$

$\Rightarrow$ Highly damaged stem, with total damaged surface area $>10 \mathrm{dm}^{2}$

Table 1 Stand and site characteristics of 17 forest stands (subcompartments) where M. giganteus infected trees were found, with number of observed and analyzed infected trees

\begin{tabular}{|c|c|c|c|c|c|c|}
\hline $\begin{array}{l}\text { Subcompartment } \\
\text { Management unit }\end{array}$ & Age & Soil quality class ${ }^{1}$ & $\begin{array}{c}\text { Average stand height } \\
\mathrm{m}\end{array}$ & $\begin{array}{c}\text { Height above sea level } \\
\mathrm{m}\end{array}$ & $\begin{array}{c}\text { Growing stock } \\
\mathrm{m}^{3} / \mathrm{ha}\end{array}$ & $\begin{array}{c}\text { Number of } \\
\text { infected trees/analyzed trees }\end{array}$ \\
\hline $\begin{array}{l}\text { 41b } \\
\text { Polum-Medenjak }\end{array}$ & 112 & $|/| \mid$ & 35.0 & 195-225 & 544 & $42 / 28$ \\
\hline $\begin{array}{c}\text { 42a } \\
\text { Polum-Medenjak }\end{array}$ & 112 & $|/| \mid$ & 34.6 & $200-230$ & 499 & $41 / 22$ \\
\hline $\begin{array}{c}\text { 41a } \\
\text { Polum-Medenjak }\end{array}$ & 112 & $|/| \mid$ & 35.0 & $195-225$ & 511 & $19 / 7$ \\
\hline $\begin{array}{l}44 \mathrm{~b} \\
\text { Novigradska planina }\end{array}$ & 116 & $\|$ & 32.3 & $220-250$ & 524 & $11 /-$ \\
\hline $\begin{array}{c}\text { 43a } \\
\text { Polum-Medenjak }\end{array}$ & 118 & $|/| \mid$ & 34.2 & $200-240$ & 597 & $7 /-$ \\
\hline $\begin{array}{l}44 a \\
\text { Novigradska planina }\end{array}$ & 113 & $\|$ & 32.7 & $215-260$ & 514 & $6 / 5$ \\
\hline $\begin{array}{c}\text { 41c } \\
\text { Polum-Medenjak }\end{array}$ & 119 & $|/| \mid$ & 34.1 & 190-205 & 422 & $6 / 4$ \\
\hline $\begin{array}{c}\text { 93a } \\
\text { Polum-Medenjak }\end{array}$ & 114 & $\|$ & 33.1 & $210-270$ & 414 & $4 / 1$ \\
\hline $\begin{array}{c}\text { 73a } \\
\text { Kalnik-Kolačka }\end{array}$ & 133 & $|/| \mid$ & 34.0 & 175-235 & 232 & $4 /-$ \\
\hline $\begin{array}{c}\text { 45d } \\
\text { Polum-Medenjak }\end{array}$ & 112 & $\|$ & 34.4 & $220-230$ & 559 & $3 / 2$ \\
\hline $\begin{array}{c}\text { 39d } \\
\text { Dugačko brdo }\end{array}$ & 119 & I & 36.2 & 210-260 & 433 & $3 / 2$ \\
\hline $\begin{array}{c}4 a \\
\text { Polum-Medenjak }\end{array}$ & 112 & $\|$ & 33.0 & 190-250 & 550 & $2 / 1$ \\
\hline $\begin{array}{l}\text { 37b } \\
\text { Polum-Medenjak }\end{array}$ & 118 & $|/| \mid$ & 34.0 & 190-220 & 327 & $2 / 1$ \\
\hline $\begin{array}{c}\text { 60c } \\
\text { Polum-Medenjak }\end{array}$ & 100 & $\|$ & 31.0 & 210-260 & 451 & $1 /-$ \\
\hline $\begin{array}{c}\text { 14a } \\
\text { Mesarica-Plavo }\end{array}$ & 118 & $\|$ & 33.0 & 190-250 & 378 & $1 /-$ \\
\hline $\begin{array}{c}\text { 25c } \\
\text { Đurđevačka } \\
\text { Bilogora }\end{array}$ & 99 & I & 32.3 & 205-260 & 496 & $1 /-$ \\
\hline $\begin{array}{c}\text { 33a } \\
\text { Dugačko brdo }\end{array}$ & 119 & I & 34.4 & $210-270$ & 444 & $1 / 1$ \\
\hline
\end{tabular}

${ }^{1}$ Forest stand soil quality classes from most to least productive ones are marked as: I, II, III and IV

${ }^{2}$ Number of infected trees is number of trees with observed $M$. giganteus infection per subcompartment, and number of analyzed trees is number of infected trees which were windthrown

or cut for further false heartwood analysis in each subcompartment

* Subcompartments in which some of the infected trees were selected for further analysis are given in bold 


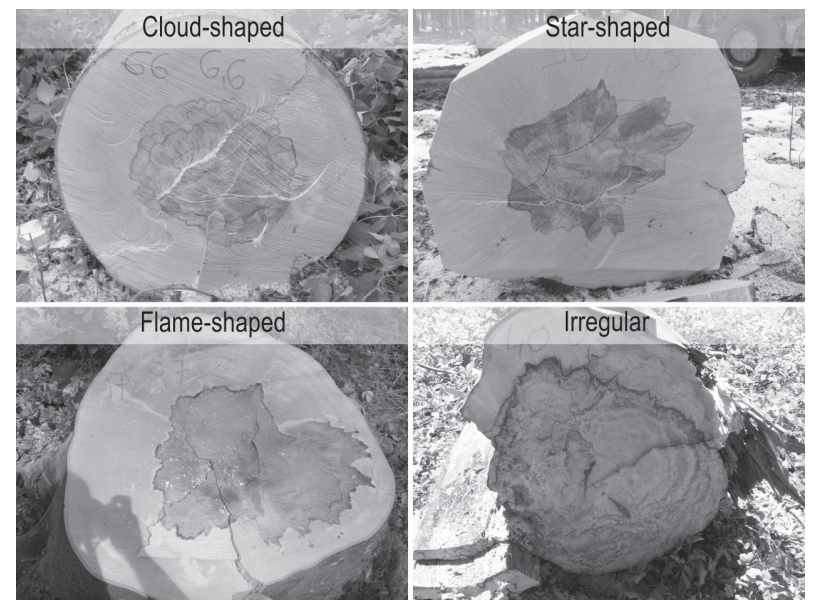

Fig. 2 Classification of false heartwood shapes used in this research

Time of fruiting bodies emergence and their life span were monitored weekly during August, September and October from 2012 to 2015. Position on a tree was recorded for each developed group of fruiting bodies during the entire research period.

In total, 74 infected trees in the 11 subcompartments were selected for further $\mathrm{FH}$ analysis, amongst the ones which were windthrown or cut according to forest management plans during the research period (Table 1). Diameter of FH and stem without bark were measured on 1-4 cross-sections per tree at different heights, depending on the wood assortment classification and processing. For both parameters, mean value of minimum and maximum diameter rounded down to full centimeter was used for further calculations of FH share in the associated stem cross-section. For 54 regularly cut trees the height of the first cross-section was $0.3 \mathrm{~m}$, whilst for 20 windthrown ones this height varied between 0.5 and $1.5 \mathrm{~m}$. Shapes of $\mathrm{FH}$ at the given cross-sections were observed and classified as cloud-, star-, flame-shaped or irregular (Mahler and Höwecke 1991, Sachsse 1991, Seeling 1998) (Fig. 2). In 50 infected trees, the length of rot associated with FH was measured in longitudinal section of the first, economically most valuable wood assortment.

As $68 \%$ of the analyzed infected trees were selected in the MU Polum-Medenjak (PM), subcompartments $41 \mathrm{~b}$ (20 cut +8 windthrown) and $42 \mathrm{a}$ (12 cut +10 windthrown) (Table 1), uninfected trees for comparative analysis were selected in the same forest stands, in the vicinity to the infected ones, to avoid any possible effect of stand or site characteristics on the results. For 36 common beech trees without signs of Meripilus giganteus infection, cut in the subcompartment PM 42a, false heartwood share in the associated stem cross-section was measured and calculated at the height of $0.3 \mathrm{~m}$ and one or two additional heights along the stem, as described for infected trees. For additional 39 trees without signs of Meripilus giganteus infection, cut in the subcompartment PM 41b, FH share in the associated cross-section was measured and calculated and its shape determined at the height of $0.3 \mathrm{~m}$, as described above.

The share of FH in stem cross-section at $0.3 \mathrm{~m}$ height was compared among $M$. giganteus infected and uninfected trees in two most affected forest stands, subcompartments PM 41b and PM 42a, using Factorial ANOVA. For the $p<0.05$, Tukey HSD test was used to show which categories make a significant difference. Linear regression analysis was conducted to detect the effect of stem height on FH share for both groups of trees from subcompartment PM 42a, for which data on at least two different heights were available. As stem height showed to be a significant predictor, a One-way ANCOVA was performed to compare the FH share between infected and uninfected trees whilst accounting for this variable. Since ANCOVA results revealed the violation of homogenity of regression slopes assumption, indicating an interaction between M. giganteus infection status and stem height, Potthoff modified Johnson-Neyman method was employed to define the value of the stem height at which infected and uninfected trees differ significantly regarding the share of FH in stem cross-section. Fisher's exact test was used to explore the effect of stem damage category on FH shape at $0.3 \mathrm{~m}$ stem height and on presence of rot in infected trees. Association between tree infection status and $\mathrm{FH}$ shape at $0.3 \mathrm{~m}$ stem height was analyzed using a chi-square test of independence. One-way ANOVA was used to test if there is statistically significant difference in length of rot in a butt-log and $\mathrm{FH}$ share at the height of $0.3 \mathrm{~m}$ across different stem damage categories. Analyses were performed in software package Statistica 10 (StaSoft Inc. 2011).

\section{Results}

Infected trees observed in this research (154) were 99 to 133 years old (averagely 114 \pm ), distributed in DBH classes ranging from 32.5 to $112.5 \mathrm{~cm}$, with most of them belonging to $77.5 \mathrm{~cm} \mathrm{DBH}$ class (Fig. 3). The first appearance of fruiting bodies on a tree was noted on August 10 at the earliest and on October 31 at the latest in the year. Life span of fruiting bodies on a tree in one season was 4.2 weeks on average, with minimum of one and maximum of nine weeks (Appendix A, Fig. A1). It was observed that massive sporulation visible as white powder occurs in the third and fourth week of basidiocarp development. In total there were 345 findings of M.giganteus fruiting bodies during the 


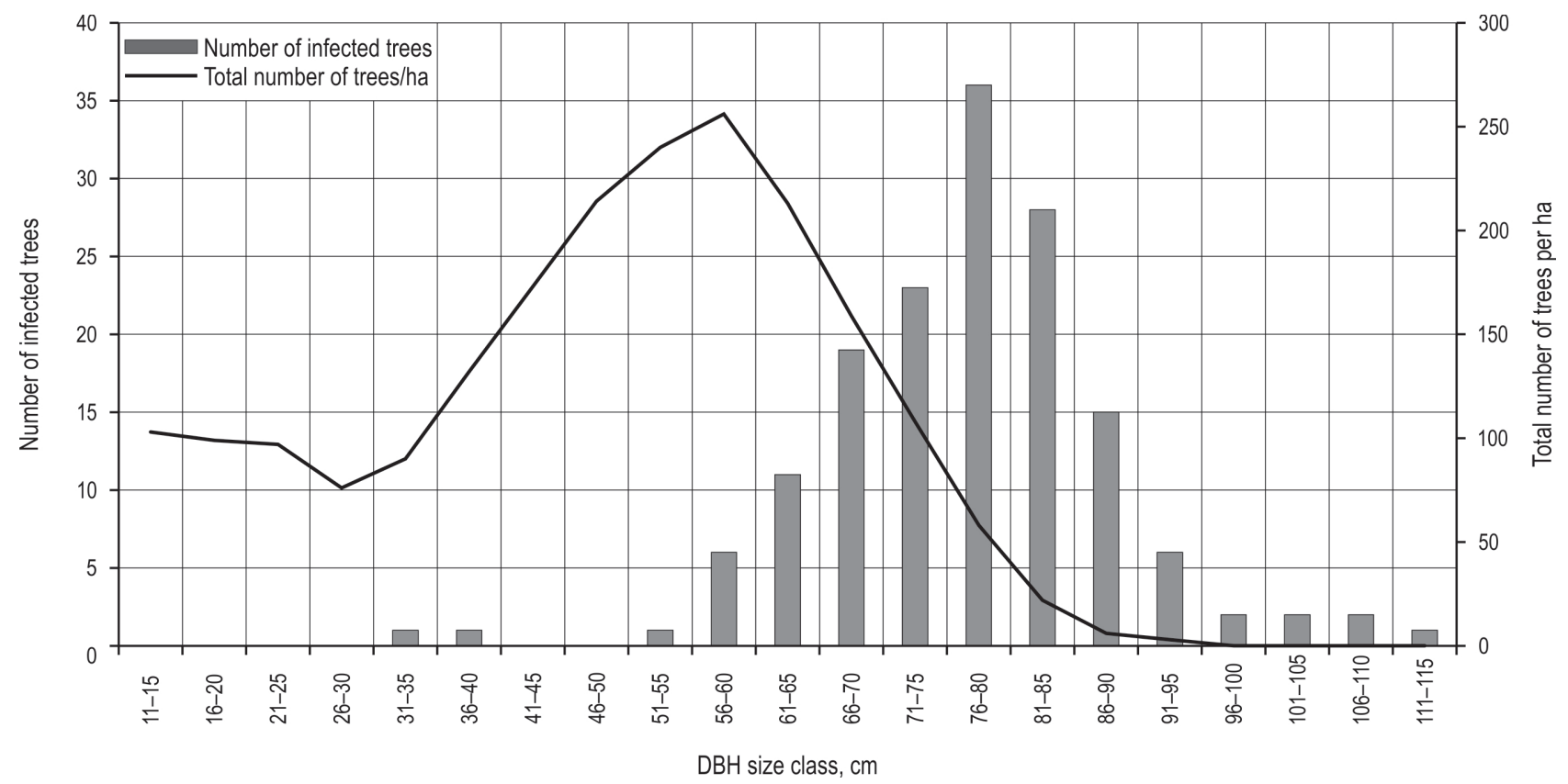

Fig. 3 Distribution of Meripilus giganteus infected Fagus sylvatica trees in DBH classes

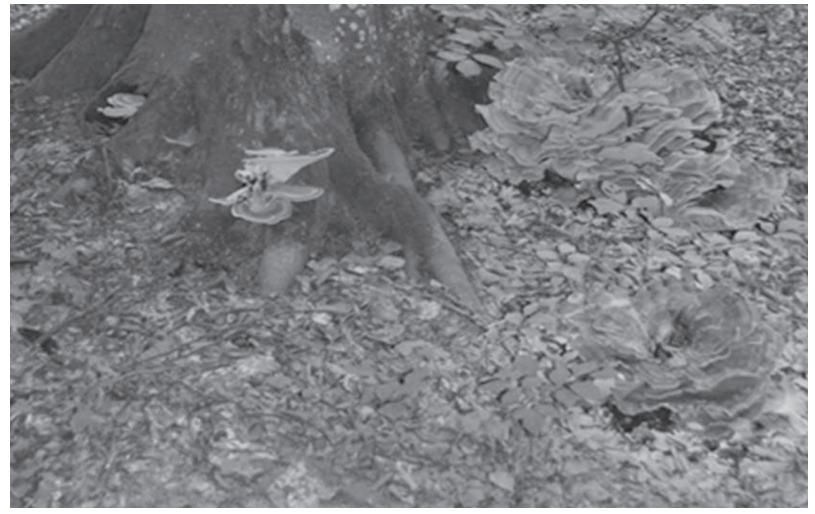

Fig. 4 Meripilus giganteus fruiting bodies growing both on roots and root collars of a single tree in one season. Sporulation is visible as a white powder on the surrounding leaf litter

entire research period, of which 280 were only on root collars, 21 only on roots and 44 on both at the same time and on the same tree (Fig. 4). They developed on 69 trees with undamaged stem. As for the mechanically wounded ones, the fungus was observed on roots and root collars of 46 trees with slightly, 18 with moderately and 21 with highly damaged stems.

\subsection{Impact of Meripilus giganteus on False Heartwood Shape}

All analyzed infected trees (74) and 73 (of 75) uninfected trees revealed the presence of $\mathrm{FH}$ on all in- spected cross-sections. Analysis of the FH shape noted on 231 cross-sections at different stem heights in 74 infected trees showed that star-shaped FH prevailed in lower and cloud-shaped FH in higher parts of the stem (Fig. 5).

For 54 infected and 39 uninfected regularly cut trees, FH shape on the front end of a butt-log was

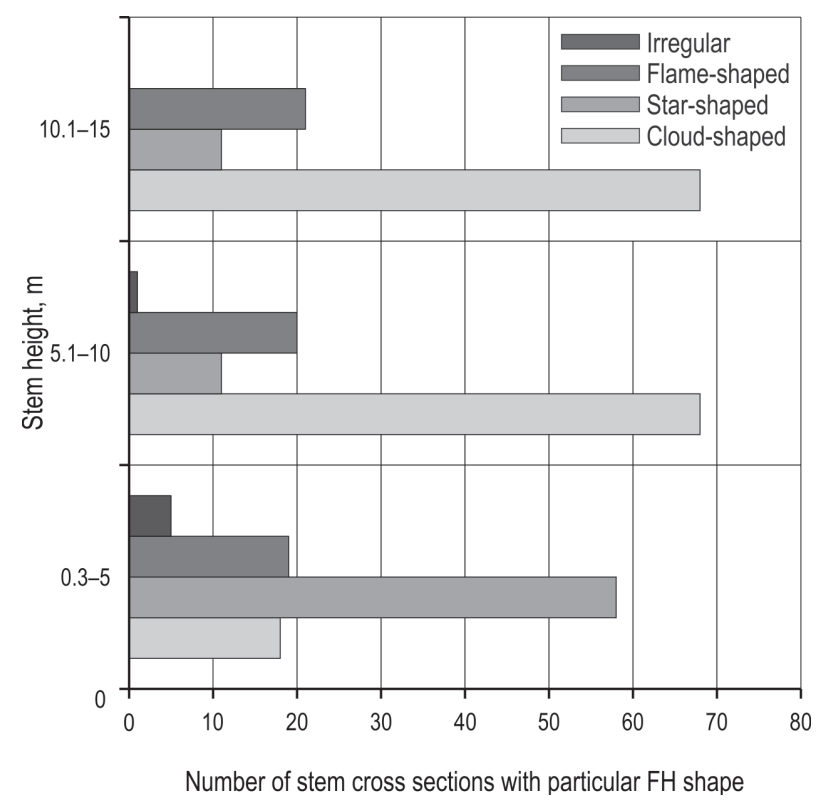

Fig. 5 Occurrence of classified false heartwood shapes at different stem heights in Meripilus giganteus infected trees 
observed at $0.3 \mathrm{~m}$ height. Fisher's exact test revealed that there is no significant association between the stem damage category and the shape of $\mathrm{FH}$ at this height in infected trees $(p=0.190)$. At the given height, most of the infected trees (47) displayed star-shaped $\mathrm{FH}$, followed by four, two and one tree with irregular, flame-shaped and cloud-shaped $\mathrm{FH}$, respectively. On the majority of these trees, the shape of FH changed along the stem, with 32 trees revealing two and 13 trees three different $\mathrm{FH}$ shapes. As for the uninfected trees, $\mathrm{FH}$ at $0.3 \mathrm{~m}$ height was cloud-shaped on 23, star-shaped on nine, flame-shaped on five and not present on two cross-sections. A chi-square test of independence revealed a significant relationship between tree infection status, i.e. Meripilus giganteus presence and shape of $\mathrm{FH}$ at the height of $0.3 \mathrm{~m}\left[\mathrm{X}^{2}\right.$ $(3, N=60)=29.82, p<0.001]$.

\subsection{Impact of Meripilus giganteus on False Heartwood Size}

The share of $\mathrm{FH}$ at $0.3 \mathrm{~m}$ height in $M$. giganteus infected trees was $70.63 \%$ on average $(\mathrm{SD}=13.78 \%)$, whilst in uninfected trees it was $26.89 \%$ (SD=11.90\%). Statistically significant effect of stem damage category on FH share at this height was not confirmed by a One-way ANOVA $[F(3,50)=1.085 ; p=0.364]$. The share of $\mathrm{FH}$ at $0.3 \mathrm{~m}$ was compared between 32 infected and 73 uninfected trees from two most affected forest stands, subcompartments PM 41b and PM 42a. Factorial ANOVA test revealed that FH share at the given height was significantly different between infected and uninfected trees $(F(1,102)=276.51 ; p<0.001)$, whereas there was no statistically significant difference between trees from different subcompartments, $41 \mathrm{~b}$ and $42 \mathrm{a}(F(1,102)=3.164 ; p=0.078)$. Tukey HSD post hoc test confirmed these results (Table 2).

Linear regression analysis of stem height effect on FH share was performed on 12 infected (32 cross-sections) and 32 uninfected (71 cross-sections) trees from the same forest stand, subcompartment PM 42a. Results revealed that: a) FH share could be statistically

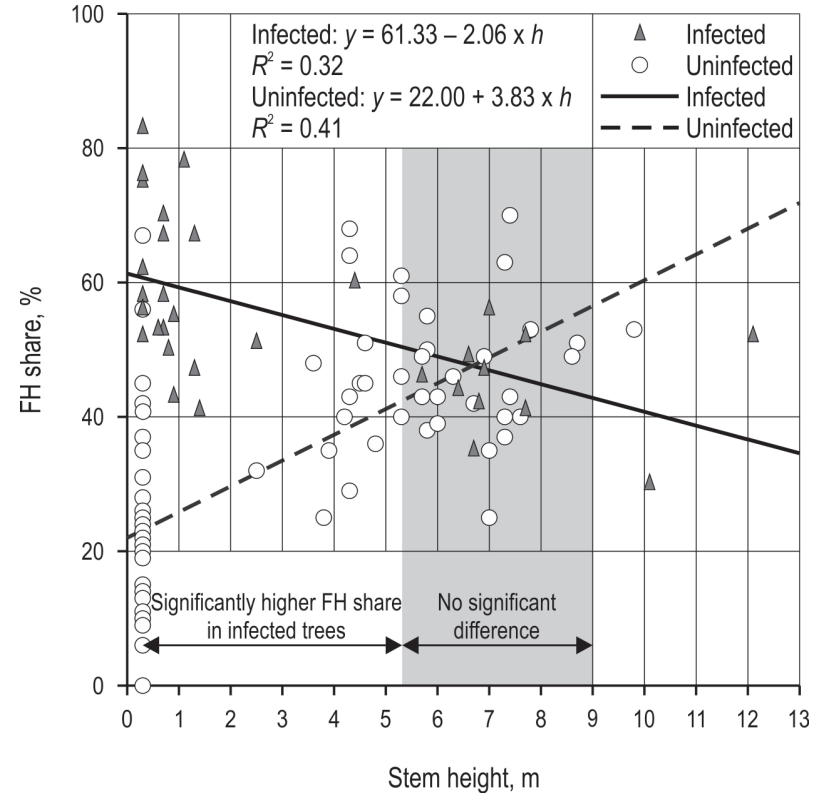

Fig. 6 Linear regression analysis of effect of stem height on false heartwood share in $M$. giganteus infected and uninfected common beech trees, showing stem height value interval where difference in $\mathrm{FH}$ share between groups of trees is statistically significant $(p<0.05)$ based on Potthoff modified Johnson-Neyman method

significantly predicted based on stem height in both infected $[F(1,30)=14.11, p<0.001]$ and uninfected trees $[F(1,69)=48.04, p<0.001]$; and b) $F H$ share decreased in infected $\left(R^{2}=0.32\right)$ and increased in uninfected trees $\left(R^{2}=0.41\right)$ with the increase of stem height (Fig. 6).

A one-way ANCOVA showed a significant difference between regression coefficients for two groups of trees $(t=-6.920, p<0.001)$, meaning that tree infection status affects the association between stem height and FH share. Potthoff modified Johnson-Neyman method established that infected trees have statistically significantly higher $\mathrm{FH}$ share at stem height $\leq 5.3 \mathrm{~m}$ and that there is no significant difference in FH share between infected and uninfected trees at stem height from $5.3 \mathrm{~m}$ to $9 \mathrm{~m}$ (Fig. 6).

Table 2 Results of Tukey HSD post hoc test for the effect of M. giganteus infection and forest stand (subcompartment) on false heartwood share at stem height of $0.3 \mathrm{~m}$ ( $p$ values less than 0.05 are given in bold)

\begin{tabular}{|c|c|c|c|c|}
\hline & Uninfected trees/PM 42a & Uninfected trees/PM 41b & Infected trees/PM 42a & Infected trees/PM 41b \\
\hline Uninfected trees/PM 42a & - & 0.9652 & $\mathbf{0 . 0 0 0 1}$ & $\mathbf{0 . 0 0 0 1}$ \\
\hline Uninfected trees/PM 41b & 0.9652 & - & $\mathbf{0 . 0 0 0 1}$ & $\mathbf{0 . 0 0 0 1}$ \\
\hline Infected trees/PM 42a & $\mathbf{0 . 0 0 0 1}$ & $\mathbf{0 . 0 0 0 1}$ & - & 0.2732 \\
\hline Infected trees/PM 41b & $\mathbf{0 . 0 0 0 1}$ & $\mathbf{0 . 0 0 0 1}$ & 0.2732 & - \\
\hline
\end{tabular}




\subsection{Occurrence and Size of Rot in Infected Trees}

Rot was present on stump and front end of a butt$\log$ in 60 of 74 analyzed infected trees (Fig. 7). Fisher's exact test revealed that there is no significant association between stem damage category and presence of $\operatorname{rot}(p=0.336)$. The length of rot in the longitudinal section of a butt-log was measured for 50 trees, where there was no observable impact of other factors on its spread along the stem, such as crown damage or tree wilt, which could contribute to the presence of other rot fungi. The length of rot in a butt-log varied from 0.1 to $1.3 \mathrm{~m}$, with an average value of $0.5 \mathrm{~m}(\mathrm{SD}=0.29 \mathrm{~m})$. Statistically significant difference in length of rot among stem damage categories was not determined by Oneway ANOVA $[F(3,46)=0.853, p=0.472]$.

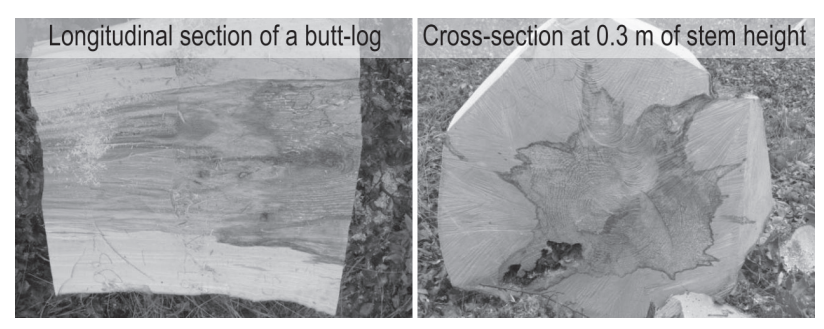

Fig. 7 Example of wood decay caused by M. giganteus

\section{Discussion}

Fruiting bodies of Meripilus giganteus were found in 17 forest stands across the monitored area, on mature trees ageing between 99 and 133 years at the moment of the first notification of fungus, confirming the increase of common beech susceptibility to infection with age (Zmitrovich et al. 2019). More than half of infected trees were situated in two neighboring subcompartments characterized by same age and similar growth conditions, PM 42a and PM 41b (MU PolumMedenjak). Given that wood-decay fungi predominantly spread via basidiospores produced in fruiting bodies, it is plausible that $M$. giganteus has been present in these most affected stands for a longer period of time, cumulatively building up the inoculum and infecting more trees, meaning that with time it could spread similarly in other subcompartments, where it was confirmed in lower numbers. Young fruiting bodies were noticed in summer and autumn, as reported in literature (Krisai-Greilhuber 1992, Božac 2003, Schmidt 2006), on August 10 at the earliest and on October 31 at the latest in the year, with a life span between one and nine weeks, and massive sporulation in the third to fourth week. This data indicate the time frame when the fungus presence inside a tree can be recognized on the stem and also the time period when new infections can occur. As fruiting bodies are of limited life span and deteriorate in 4 weeks on average, change in their appearance as shown in Appendix A, Fig. A1, should be taken into consideration when notifying tree infection status.

Wood-decay fungi are mostly wound penetrating pathogens. However, in this study there was a significant number of infected trees (45\%) without any visible stem damage, and notifications of highly damaged uninfected trees in their close proximity (data not shown), implying that stem damage does not have a decisive effect on infection. This could be explained with fungus preference to infections via old dead or damaged large roots, as stated by Schwarze et al. (2000). However, basidiocarps were predominantly found on root collars and to a lesser extent on roots, indicating the spread of fungal mycelium in stem base, where it could affect properties and value of the first wood assortment. In addition to $74 M$. giganteus infected trees, which revealed FH on all analyzed stem cross-sections, 73 out of 75 uninfected trees in this research developed FH as well. This confirms the broadly accepted hypothesis that FH formation is under the influence of factors other than fungal infections, in this case most probably the maturity and increased diameter of trees, as proposed by Prka et al. (2009), which is linked to decreased moisture content and vitality of parenchyma cells in central stem (Zycha 1948, Torelli 1984, Bauch and Koch 2001). It was thus assumed that the activity of $M$. giganteus causes enlargement and change of already present $\mathrm{FH}$ in infected beech trees, decreasing mechanical and aesthetic properties of processed logs and leading to further loss of value, as noted by several authors for wood-decay fungi in general (Wernsdörfer et al. 2005, Trenciansky et al. 2017, Piętka et al. 2019).

Indeed, the shape of FH at the front cross-section of a butt-log (stem height of $0.3 \mathrm{~m}$ ) showed to be significantly different between infected and uninfected trees, being mostly star shaped on trees where M. giganteus was present and cloud shaped in visually healthy ones $(p<0.001)$. Given that the observed mechanical stem damage did not have a significant effect on FH form according to the results of Fisher's exact test $(p=0.190)$, it can be concluded that the fungus is most responsible for the development of star shaped $\mathrm{FH}$ at the height of $0.3 \mathrm{~m}$, as suggested by Necesany (1958) for fungi in general. Clear visual associations between FH shape and wounds in beech trees were not found by Wernsdörfer et al. (2005) either. In the majority of infected trees (83\%), the shape of $\mathrm{FH}$ changed along the stem, which is a phenomenon also 
observed on beech trees without signs of fungal infection in previous studies (Prka 2003, Trenciansky et al. 2017). Star-like FH prevailed in lower parts of stem of infected trees, whereas cloud-like one predominated above $5 \mathrm{~m}$ of stem height. Since the latter one is a typical form of sound heartwood as indicated by some authors (Sachsse 1991, Trenciansky et al. 2017), and given the previous results, it is possible that $M$. giganteus effect on FH shape might extend to as much as $5 \mathrm{~m}$ along the beech trunk. However, this should not be taken as the exact value, since no comparable observations at different stem heights were made on uninfected trees in this study.

False heartwood diameter at the front end of the first processed log, expressed as a share in diameter of stem cross-section at $0.3 \mathrm{~m}$, was significantly bigger in infected trees, averagely amounting to more than $70 \%$, in comparison with uninfected trees, where the average share was less than $27 \%(p<0.001)$. No effect of stem damage category on $\mathrm{FH}$ share at this height was found ( $p=0.364)$, implicating that $M$. giganteus infection and spread has a prevailing effect on FH enlargement at the stem base. The impact of forest stand characteristics was also excluded, as there was no significant difference in $\mathrm{FH}$ size between the two most affected subcompartments (PM 41b and PM 42a, $p=0.078$ ), which is not surprising, as they are of the same age and corresponding properties. Račko et al. (2018) reported similar findings of no significant difference in discoloration, decay and red heartwood formation even among different sites and beech stands, opposite to some authors who found that growth conditions in forest can influence the heartwood ocurrence (Torelli 1984, Büren 1997, Furst et al. 2006).

In both infected and uninfected trees, the share of FH significantly depended on stem height $(p<0.001)$, supporting the findings of other studies (Knoke and Wenderoth 2001, Račko and Čunderlík 2002). Most importantly, it was decreasing towards stem top in $M$. giganteus affected trees, and increasing in visually healthy ones. Other studies conducted on trees without visible fungal infections report that proportions of FH are usually the lowest in stem butts, and culminate at stem height of approximately 4-8 m (Racz et al. 1961, Krempl and Mark 1962, Vasiljevič 1974, Arač 2005 ) or at $30-50 \%$ of the tree height (Sachsse 1991). This is explained by the fact that FH often forms in the crown and at stem bifurcations or branch scars, from where it extends downwards (Keller 1961, Wernsdörfer et al. 2006). The results obtained in this research thus imply that $M$. giganteus also causes significant increase of FH share above the stem height of $0.3 \mathrm{~m}$, however, still in lower parts of beech trunks in com- parison to uninfected trees. Using Potthoff modified Johnson-Neyman method, it was established that this significant impact extends to the height of $5.3 \mathrm{~m}$, similar to the presumed height of fungus influence on $\mathrm{FH}$ shape, whereas no significant difference was found in $\mathrm{FH}$ size between 5.3 and $9 \mathrm{~m}$ stem height compared to uninfected trees. These results are in accordance with aforementioned studies reporting stem sections where size of sound FH reaches the highest values.

$M$. giganteus caused visible decay in the majority of analyzed trees (81\%), extending averagely $0.5 \mathrm{~m}$ in a butt-log, with maximum rot length of even $1.3 \mathrm{~m}$. These results confirm detrimental effect of fungus on value loss as observed in previous research (Wernsdörfer et al. 2005, Trenciansky et al. 2017, Piętka et al. 2019), since these parts of round wood need to be sawn off in order to classify the rest of the log in one of wood assortment quality classes, which leads to decrease of volume of most valuable trunk part. Statistical analysis confirmed that M. giganteus infection had predominant impact on both occurrence and expansion of decay, as there was no significant association between stem damage category and these parameters $(p=0.336$; $p=0.472$; respectively). Similar results were reported by Schumann and Dimitri (1993), who found only $25 \%$ of mechanical stem wounds to be infected by fungi, and Diehl and Seidenschnur (1990) who concluded that beech is more resistant to wound-invading microorganisms in comparison with other species. This points to negligible possibility of presence of other wooddecay fungi and corroborates the conclusion that M. giganteus caused the rot spreading from roots and root collars. However, $19 \%$ of the analyzed infected trees were decay free at the stump cross-section, which could be explained by biology of fungus and its probable presence in basal parts of tree under the height of the first cut $(0.3 \mathrm{~m})$ (Zmitrovich et al. 2019), from where it would probably spread up the stem and cause rot with time, being only moderately invasive considering the rate of beech wood degradation as observed by Piętka et al. (2019).

Overall results presented in this research indicate that $M$. giganteus has a significant effect on $\mathrm{FH}$ and rot in lower stem sections of beech trees, which are considered to be the most valuable parts of round wood. According to Bachmann (1990), the lower third of the trunk represents $60 \%$ of the volume and $90 \%$ of the value of the entire tree stem. European Union standards for beech round wood classification (HRN EN 1316-1:2012) list FH shape and size and rot ocurrence and size as limiting factors for allocating processed logs in higher quality classes. According to these, star shaped FH and central rot are not permitted in most 
valuable A class assortments, and are limited to $15 \%$ of assortment diameter in B, and $40 \%$ and $25 \%$ of assortment diameter in C quality class, respectively. The share of $\mathrm{FH}$ is limited to $15 \%$ and 30\% of assortment diameter in A and B quality classes. As $87 \%$ of M. giganteus infected trees in this research revealed star-shaped $\mathrm{FH}$ at the height of $0.3 \mathrm{~m}$, taking up averagely $70 \%$ of associated cross-section, and being affected by decay in $81 \%$ analyzed trees, almost certainly none of the butt-logs could be classified as A or B quality class assortments. Since fungal impact on $\mathrm{FH}$ showed to extend up to approximately $5 \mathrm{~m}$, the second wood assortment is under a risk of degradation in lower quality class as well. Although decay caused by $M$. giganteus developed only in butt-logs (up to $1.3 \mathrm{~m}$ ), this parameter is the most limiting one for log allocation in higher quality classes among the three ones observed according to EU standards. This is not surprising given that decay leads to significant rise in moisture content and loss of net calorific value, decreasing commercial value even of wood used as energy biomass (Piętka et al. 2019). Appointing processed logs to lower quality classes due to the so called unhealthy heartwood (star-shaped and/or decayed) causes significant losses of revenues from the sale of beech timber assortments, up to $20.48 € / \mathrm{m}^{3}$ in comparison with loss of $5.38 € / \mathrm{m}^{3}$ caused by sound forms of FH (Trenciansky et al. 2017).

\section{Conclusions}

Meripilus giganteus distribution established in this research was limited to mature, more than 99 years old even-aged beech stands, confirming the increase of tree susceptibility to infections with age. The fungus predominantly attacked trees with none or only small visible mechanical wounds that could represent entrance points, implying that the majority of infections occurs via roots, from where the mycelium spreads upwards to the stem base, as fruiting bodies found in this study mostly developed on root collars. Generally, infection can be noticed only after emergence of fruiting bodies, which also serve as reservoirs of spores for further spread, mostly in the third and fourth week of their growth. Time frame for infection occurrence and recognition in this study was set to early August until November, possibly December, depending on the period of basidiocarp development and deterioration, which can last between one and nine weeks according to observations made.

As FH was noted not only on infected, but also on the majority of uninfected trees, it can be concluded that fungus does not have a decisive role in its formation, and that it is most probably the consequence of tree age and diameter increase as stated by other authors. Nevertheless, comparisons between infected and visually healthy trees showed that $M$. giganteus significantly affects the shape and size of already present FH up to about $5 \mathrm{~m}$ of stem height, causing its enlargement and metamorphosis from cloud- to star-shaped forms. The other detrimental effect of the fungus was revealed to be heart rot, extending averagely $0.5 \mathrm{~m}$ in the first wood assortment in the majority of infected trees, causing the loss of utilizable volume as these parts of round wood have to be sawn off due to impaired mechanical and technical properties. However, 19\% of infected trees with no observable rot on the cross-section of the first cut, imply slower advance of decay from roots to stem bases in some cases, which gives forest managers the opportunity to utilize entire round wood of affected tree if the infection is noted on time.

Stem damage category showed to have no significant impact on FH shape and size, and occurrence and size of heart rot, confirming the prevailing role of the fungus. By affecting aforementioned parameters, $M$. giganteus subsequently has a significant impact on beech processed logs allocation in quality classes according to EU standards (HRN EN 1316-1:2012), which list them as limiting wood faults. Due to frequent occurrence of star-shaped and rot affected $\mathrm{FH}$, encompassing on average about $70 \%$ of the first cut cross-section, almost certainly none of the butt-logs in analyzed infected trees could be designated to the highest quality classes. Given that fungal impact extended to the length of a second wood assortment, it is most likely that these sections of round wood would be appointed to lower quality classes as well.

The results presented in this study confirm harmful impact of $M$. giganteus infection on quality and thus the value of common beech round wood, by affecting the size and shape of FH and causing wood decay. Although the majority of infections noted in this research showed to be limited to two neighboring forest stands, the fungus could spread in others with time and cause devaluation if appropriate management measures are not undertaken, as mature stands are more susceptible to both FH formation and infection. Proposed management measures would be to monitor mature beech stands regularly for the signs of infection, i.e. fruiting bodies, and remove trees in the early stages of the process to prevent loss of round wood quality and further spread of the fungus.

\section{Acknowledgments}

This research was carried out with the financial and technical support of the Croatian Forests Ltd. 


\section{References}

Albert, L., Hofmann, T., Németh, Z.I., Rétfalvi, T., Koloszár, J., Varga, S., Csepregi, I., 2003: Radial variation of total phenol content in beech (Fagus sylvatica L.) wood with and without red heartwood. Holz als Roh-und Werkstoff 61(3): 227-230. https://doi.org/10.1007/s00107-003-0381-x

Anon., 2016: Šumskogospodarska osnova područja Republike Hrvatske za razdoblje 1.1.2016.-31.12.2025., Croatian Forests Ltd., Zagreb, Croatia.

Arač, K., 2005: Uzročnici truleži drva i crveno srce obične bukve (Fagus sylvatica L.) u gospodarskoj jedinici »Polum Medenjak « - šumarija Sokolovac. Master Thesis, University of Zagreb Faculty of Forestry, Zagreb, Croatia, 122 p.

Babiak, M., Čunderlík, I., Kúdela, J., 1990: Permeability and structure of beech wood. IAWA bulletin 11(2): 115-115.

Bachmann, P., 1990: Produktionssteigerung im Wald durch vermehrte Berücksichtigung des Wertzuwachses. Eid. Forschungsanstalt für Wald Schnee und Landschaft, 1-327 p.

Barański, J., Klement, I., Vilkovská, T., Konopka, A., 2017: High temperature drying process of beech wood (Fagus sylvatica L.) with different zones of sapwood and red false heartwood. BioResources 12(1): 1861-1870.

Bauch, J., Koch, G., 2001: Biologische und chemische Untersuchungen über Holzverfärbungen der Rotbuche (Fagus sylvatica [L.]) und Möglichkeiten vorbeugender Maßnahmen; Bundesforschungsanstalt für Forst- und Holzwirtschaft, Universität Hamburg: Hamburg, Germany.

Bondartsev, A., 1953: Polyporaceae of the European part of USSR and Caucasus. Moskow, Leningrad, Russia, 1-1106 p.

Bosshard, H.H., 2013: Holzkunde: Band 2 Zur Biologie, Physik und Chemie des Holzes. Springer-Verlag, vol. 19.

Božac, R., 2003: Gljive: morfologija, sistematika, toksikologija. Školska knjiga: Zagreb, Croatia, 1-423 p.

Büren, S., 1997: Untersuchungen über die Verbreitung, die Erkennung am stehenden Baum und die ökonomischen Auswirkungen: der Farbkern der Buche (Fagus sylvatica L.) in der Schweiz nördlich der Alpen. Doctoral Thesis, Swiss Federal Institute of Technology (ETH), Zürich, Switzerland, 187 p.

Čavlović, J., 2010: Prva nacionalna inventura šuma Republike Hrvatske. Ministry of Regional Development, Forestry and Water Management, University of Zagreb, Faculty of Forestry: Zagreb, Croatia, 1-300 p.

Čavlović, J., Božić, M., 2008: Nacionalna inventura šuma u Hrvatskoj-metode terenskog prikupljanja podataka. University of Zagreb, Faculty of Forestry: Zagreb, Croatia, 1-146 p.

Diehl, M., Seidenschnur, W., 1990: Gutes überwallungsvermögen der Rotbuche bel Schälschäden im Dickungsstadium. Allgemeine Forstzeitschrift 19: 452-454.

Friedrich, S., 2006: Threatened and protected macromycetes in the Wkrzanska Forest. Acta Mycologica 41(2): 229-240. https:// doi.org/10.5586/am.2006.025

Furst, C., Seifert, T., Makeschin, F., 2006: Do site factors affect the wood quality of European beech (Fagus sylvatica L.)? Results from a pre-study on red heartwood. Forst und Holz 61(11): 464-468.
Glavaš, M., 1999: Gljivične bolesti šumskoga drveća; University of Zagreb, Faculty of Forestry: Zagreb, Croatia, 281 p.

Hapla, F., Ohnesorge, D., 2005: Qualitätsorientierte Schnittholzausbeute in Abhängigkeit von Durchmesser und Rotkernanteil bei Buchenstammholz-ein Modellansatz mit unterschiedlichen Einschnittarten. Holztechnologie 46(4): 5-9.

HRN EN 1316-1:2012, 2012: Hardwood round timber. Qualitative classification. Part 1: Oak and beech. Technical Standard of Croatia, Croatian Standards Institute, Zagreb, Croatia, 1-12 p.

Jordan, P., 2011: Prepoznavanje gljiva, ilustrirana enciklopedija. Leo commerce: Rijeka, Croatia, 132 p.

Keller, H., 1961: Vom Rotkern der Buche. Schweiz. Z. Forstwes 112(8): 498-502.

Kišpatić, J., 1980: Bolesti šumskog drveća. In Šumarska enciklopedija, JLZ: Zagreb, Croatia, 119-128 p.

Klement, I., Vilkovská, T., 2018: Analysis of the effects of drying process of red false heartwood and mature wood on the quality and physical properties of beech wood (Fagus sylvatica L.). BioResources 13(2): 4252-4263.

Knoke, T., 2003: Predicting red heartwood formation in beech trees (Fagus sylvatica L.). Ecological Modelling 169(2-3): 295312. https://doi.org/10.1016/S0304-3800(03)00276-X

Knoke, T., Wenderoth, S.S., 2001: Ein Ansatz zur Beschreibung von Wahrscheinlichkeit und Ausmaß der Farbkernbildung bei Buche (Fagus sylvatica L.). Forstwissenschaftliches Centralblatt vereinigt mit Tharandter forstliches Jahrbuch 120(1-6): 154172. https://doi.org/10.1007/BF02796089

Koch, G., Bauch, J., Puls, J., Schwab, E., Welling, J., 2000: Vorbeugung gegen verfärbungen von rotbuche. Holz-Zentralblatt 126(6): 1-6.

Koch, G., Bauch, J., Puls, J., Welling, J., 2001: Ursachen und wirtschaftliche Bedeutung von Holzverfärbungen - Interdisziplinäre Forschung am Beispiel der Rotbuche. Forschungsreport Verbraucherschutz - Ernahrung - Landwirtschaft 2: 30-33.

Krempl, H., Mark, E., 1962: Untersuchungen uber den Kern der Rotbuche. Allg. Forstztg. (Wien) 73: 186-191.

Krisai-Greilhuber, I., 1992: Die Makromyceten im Raum von Wien: Ökologie und Floristik. IHW-Verlag: Wien, Austria, $192 \mathrm{p}$.

Kucera, L., Pohler, E., 1988: Das Holz der Buche und die Farbkernbildung. Schw Z Forstw 149: 931-942.

Liu, S., Loup, C., Gril, J., Dumonceaud, O., Thibaut, A., Thibaut, B., 2005: Studies on European beech (Fagus sylvatica L.). Part 1: Variations of wood colour parameters. Annals of forest science 62(7): 625-632. https://doi.org/10.1051/forest:2005063

Magri, D., 2008: Patterns of post-glacial spread and the extent of glacial refugia of European beech (Fagus sylvatica). Journal of Biogeography 35(3): 450-463. https://doi. org/10.1111/j.1365-2699.2007.01803.x

Mahler, G., Höwecke, B., 1991: Verkernungserscheinungen bei der Buche in Baden-Württemberg in Abhängigkeit von Alter, Standort und Durchmesser. Schweizerische Zeitschrift für Forstwesen 142(5): 375-390. 
Marenče, J., Šega, B., Gornik Bučar, D., 2020: Monitoring the Quality and Quantity of Beechwood from Tree to Sawmill Product. Croatian Journal of Forest Engineering 41(1): 119-128. https://doi.org/10.5552/crojfe.2020.613

Marinescu, I., Campean, M., Budau, G., 2010: Comparison between physical properties and drying behaviour of white wood and red heart of European Beech. In Proceedings of $11^{\text {th }}$ International IUFRO Wood Drying Conference, Skelleftea, Sweden, 55-60 p.

Molnár, S., Németh, R., Fehér, S., Tolvaj, L., Papp, G., Varga, F., 2001: Technical and technological properties of Hungarian beech wood consider the red heart. Wood Research 46(1): 21-30.

Necesany, V., 1958: Jádro buku (Heartwood of beech). Slovak Academy of Sciences: Bratislava, Slovakia, 256 p.

Necesany, V., 1966: Die Vitalitätsänderung der Parenchymzellen als physiologische Grundlage der Kernbildung. Holzforschung Holzverwertung 18: 61-65.

Nienhaus, F.H., Butin, B., Böhmer, B., 1996: Farbatlas Gehölzkrankheiten Zierppäucher und Parkbäume. Ulmer Verlag: Stuttgart, Germany, 287 p.

Oven, P., Merela, M., Vek, V., 2010: Response of wood in beech to mechanical wounding. Wood Structure and Properties 10: 63-66.

Panshin, A.J., Zeeuw, C.D., 1970: Textbook of wood technology. Structure, identification, uses, and properties of the commercial woods of the United States and Canada. McGraw-Hill Book Co.: New York, USA, Vol. 1.

Piętka, J., Gendek, A., Malaták, J., Velebil, J., Moskalik, T., 2019: Effects of selected white-rot fungi on the calorific value of beech wood (Fagus sylvatica L.). Biomass and Bioenergy 127: 1-6. https://doi.org/10.1016/j.biombioe.2019.105290

Pöhler, E., Klingner, R., Künniger, T., 2006: Beech (Fagus sylvatica L.) - Technological properties, adhesion behaviour and colour stability with and without coatings of the red heartwood. Annals of forest science 63(2): 129-137. https://doi. org/10.1051/forest:2005105

Pretzsch, H., del Río, M., Ammer, Ch., Avdagic, A., Barbeito, I., Bielak, K., Brazaitis, G., Coll, L., Dirnberger, G., Drössler, L., Fabrika, M., Forrester, D.I., Godvod, K., Heym, M., Hurt, V., Kurylyak, V., Löf, M., Lombardi, F., Matović, B., Mohren, F., Motta, R., den Ouden, J., Pach, M., Ponette, Q., Schütze, G., Schweig, J., Skrzyszewski, J., Sramek, V., Sterba, H., Stojanović, D., Svoboda, M., Vanhellemont, M., Verheyen, K., Wellhausen, K., Zlatanov, T., Bravo-Oviedo, A., 2015: Growth and yield of mixed versus pure stands of Scots pine (Pinus sylvestris L.) and European beech (Fagus sylvatica L.) analysed along a productivity gradient through Europe. European Journal of Forest Research 134(5): 927-947. https://doi.org/10.1007/s10342-0150900-4

Prka, M., 2003: Occurrence of false heartwood in beech trees and technical beech roundwood coming from thinning and preparatory felling in the area of Bjelovar Bilogora. Šumarski list 128(9-10): 467-474.

Prka, M., Zečić, Ž., Krpan, A.P., Vusić, D., 2009: Characteristics and share of European beech false heartwood in felling sites of central Croatia. Croatian Journal of Forest Engineering 30(1): 37-49.
Racz, J., Schulz, H., Knigge, W., 1961: Untersuchungen uber das Auftreten des Buchenkerns. Forst Holzwirt 16: 413-417.

Račko, V., Čunderlík, I., 2002: The ripewood and false heartwood proportions at different beech stem levels. In Wood Structure and Properties, Proceedings of the $4^{\text {th }}$ IUFRO Symposium, Bystrà, Slovakia, 1-3 September; Kudela, J., Kurjatko, S., Eds.; ,Arbora Publishers, Zvolen, Slovakia, 39-41 p.

Račko, V., Čunderlík, I., 2010: Which of the factors do significantly affect beech false heartwood formation? In Proceedings of Hardwood Science and Technology, The $4^{\text {th }}$ Conference on Hardwood Research and Utilisation in Europe, Sopron, Hungary, 17 May, 94-95 p.

Račko, V., Misikova, O., Hlavac, P., Deakova, V., 2018: Can bark stripping cause red heartwood formation in beech stems? iForest - Biogeosciences and Forestry 11(2): 251-258. https:// doi.org/10.3832/ifor2147-011.

Richter, J., 2001: Buchenrotkern: Vermeiden oder Verwerten? Forst und Holz 56(20): 662-663.

Ryvarden, L., Gilbertson, R.L., 1994: European polypores: Part 2: Meripilus-Tyromyces. Fungiflora A/S: Oslo, Norway, 394-743 p.

Ryvarden, L., Melo, I., 2017: Poroid fungi of Europe. Fungiflora: Oslo, Norway, $455 \mathrm{p}$.

Sachsse, H., 1991: Kerntypen der Rotbuche. Forstarchiv 62(6): 238-238.

Schmidt, M., Nowack, S., Riebeling, R., 2011: Methods and results of quantifying beech heartwood in Hesse. Allgemeine Forst-und Jagdzeitung 182(7-8): 146-159.

Schmidt, O., 2006: Wood and Tree Fungi - Biology, Damage, Protection and Use. Springer-Verlag Berlin Heidelberg: Berlin, Germany, 336 p.

Schumann, G., Dimitri, L., 1993: Wunden und Wundfäulen bei der Buche. Allgemeine Forstzeitschrift 48: 456-460.

Schwarze, F.W.M.R., Engels, J., Mattheck, C., 2000: Host-Fungus Interactions: Development and Prognosis of Wood Decay in the Sapwood. In Fungal Strategies of Wood Decay in Trees; Springer Berlin Heidelberg: Berlin, Heidelberg, 139-167 p. https://doi.org/10.1007/978-3-642-57302-6_4

Schwarze, F.W.M.R., Fink, S., 1998: Host and cell type affect the mode of degradation by Meripilus giganteus. The New Phytologist 139(4): 721-731. https://doi.org/10.1046/j. 14698137.1998.00238.x

Seeling, U., 1998: Kerntypen im Holz-Konsequenzen für die Verwertung am Beispiel der Buche (Fagus sylvatica L.). Schweiz. Z. Forstwes 149(12): 991-1004.

Seeling, U., Sachsse, H., 1992: Abnorme Kernbildung bei Rotbuche und ihr Einfluß auf holzbiologische und holztechnologische Kenngrößen. Forst und Holz 47: 210-217.

Shigo, A.L., Hillis, W., 1973: Heartwood, discolored wood, and microorganisms in living trees. Annual review of Phytopathology 11(1): 197-222. https://doi.org/10.1146/annurev. py.11.090173.001213

Sorz, J., Hietz, P., 2008: Is oxygen involved in beech (Fagus sylvatica) red heartwood formation? Trees 22(2): 175-185. https://doi.org/10.1007/s00468-007-0187-2 
Tomiczek, C., Diminić, D., Cech, T., Hrašovec, B., Krehan, H., Pernek, M., 2007: Bolesti i štetnici urbanog drveća. University of Zagreb Faculty of Forestry, Forestry Institute Jastrebarsko: Zagreb, Croatia, 384 p.

Torelli, N., 1984: The ecology of discoloured wood as illustrated by beech (Fagus sylvatica L.). IAWA Journal 5(2): 121-127. https://doi.org/10.1163/22941932-90000875

Trenciansky, M., Lieskovsky, M., Merganic, J., Sulek, R., 2017: Analysis and evaluation of the impact of stand age on the occurrence and metamorphosis of red heartwood. iForest - Biogeosciences and Forestry 10(3): 605-610. https://doi. org/10.3832/ifor2116-010

Vasiljevič, J., 1974: Beech heartwood formation in the region of the Zrinska Gora Mountain. Šumarski List 98(7): 475-520.

Vukelić, J., Baričević, D., 2003: Šumske zajednice obične bukve u Hrvatskoj. In Obična bukva (Fagus sylvatica L.) u Hrvatskoj; Matić, S., Ed.; Academy of Forest Sciences: Zagreb, Croatia, 87-108 p.

Walter, M., Kucera, L., 1991: Vorkommen und Bedeutung verschiedener Kernformen bei der Buche (Fagus sylvatica L.). Schweizerische Zeitschrift für Forstwesen 142(5): 391-406.

Wernsdörfer, H., Constant, T., Mothe, F., Badia, M., Nepveu, G., Seeling, U., 2005: Detailed analysis of the geometric relationship between external traits and the shape of red heart- wood in beech trees (Fagus sylvatica L.). Trees 19(4): 482-491. https://doi.org/10.1007/s00468-005-0410-y

Wernsdörfer, H., Le Moguédec, G., Constant, T., Mothe, F., Nepveu, G., Seeling, U., 2006: Modelling of the shape of red heartwood in beech trees (Fagus sylvatica L.) based on external tree characteristics. Annals of Forest Science 63(8): 905-913. https://doi.org/10.1051/forest:2006074

Zell, J., Hanewinkel, M., Seeling, U., 2004: Financial optimisation of target diameter harvest of European beech (Fagus sylvatica) considering the risk of decrease of timber quality due to red heartwood. Forest Policy and Economics 6(6): 579-593. https://doi.org/10.1016/S1389-9341(03)00007-8

Zmitrovich, I.V., Kalinovskaya, N.I., Arefyev, S.P., Myasnikov, A.G., Ezhov, O.N., 2019: A northern record of Meripilus giganteus (Fr.) P. Karst., 1882 (Polyporales, Agaricomycetes) from Dubki Park, Saint Petersburg, Russia. Check List 15(6): 1093-1097. https://doi.org/10.15560/15.6.1093

Zmitrovich, I.V., Wasser, S.P., Ţura, D., 2015: Wood-inhabiting fungi. In Fungi from different substrates; Misra, J.K., Tewari, J.P., Deshmukh, S.K., Vágvölgyi, C., Eds.; CRC Press: Boca Raton, USA, 17-74 p.

Zycha, H., 1948: Über die Kernbildung und verwandte Vorgänge im Holz der Rotbuche. Forstwissenschaftliches Centralblatt 67(2): 80-109. https://doi.org/10.1007/BF02083068
Authors' addresses:

Krunoslav Arač, $\mathrm{PhD}$

e-mail: krunoslav.arac@hrsume.hr

Croatian Forests Ltd.

Forest Administration Koprivnica

Department of forest ecology and protection

Ivana Meštrovića 28

48000, Koprivnica

CROATIA

Jelena Kranjec Orlović, PhD*

e-mail: jkranjec@sumfak.unizg.hr

Prof. Danko Diminić, PhD

e-mail: danko.diminic@sumfak.unizg.hr

University of Zagreb

Faculty of Forestry and Wood Technology

Department of Forest Protection and Wildlife

Management

Svetošimunska cesta 25

10000, Zagreb

CROATIA

* Corresponding author 


\section{Appendix A}
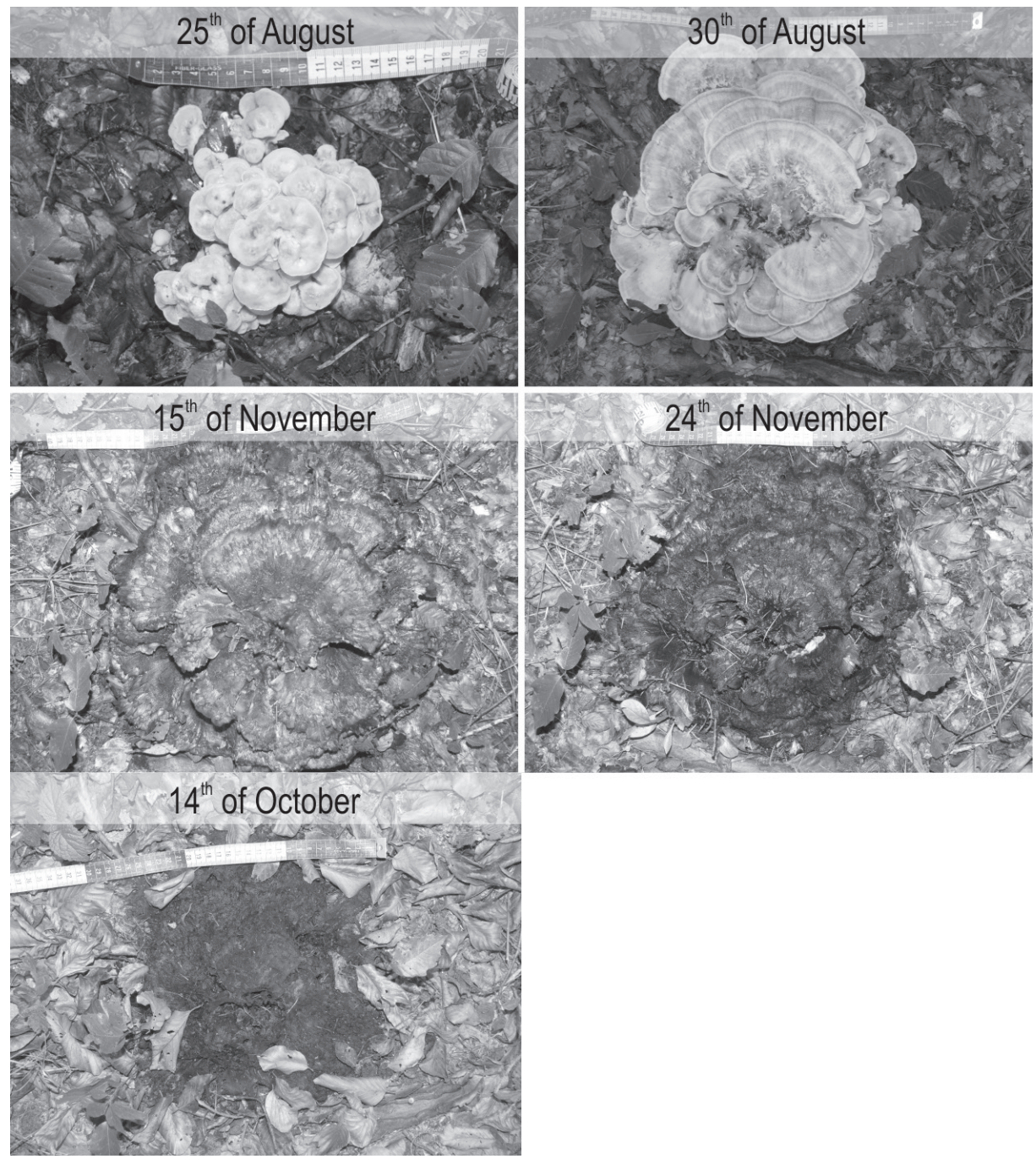

Fig. A1 Example of development and deterioration of a fruiting body in an eight-week period 